\title{
Co-combustion of agricultural residues with coal in a fluidised bed combustor
}

\begin{abstract}
Power generation from biomass is an attractive technology that utilizes agricultural residual waste. In order to explain the behavior of biomass-fired fluidised bed incinerator, biomass sources from agricultural residues (rice husk and palm kernel) were co-fired with coal in a $0.15 \mathrm{~m}$ diameter and $2.3 \mathrm{~m}$ high fluidised bed combustor. The combustion efficiency and carbon monoxide emissions were studied and compared with those for pure coal combustion. Co-combustion of a mixture of biomass with coal in a fluidised bed combustor designed for coal combustion increased combustion efficiency up to $20 \%$ depending upon excess air levels. Observed carbon monoxide levels fluctuated between 200 and 900 ppm with the addition of coal. It is evident from this research that efficient co-firing of biomass with coal can be achieved with minimal modifications to existing coal-fired boilers.
\end{abstract}

